\title{
The Critical Years: Role of the Events of the 1780s in Strengthening the Abolitionist Movement of Britain
}

\author{
Kaden Prowse
}

Throughout Britain's history in the African slave trade there had been a vocal minority of individuals that attacked the institution of colonial slavery and particularly Britain's involvement in the slave trade. Abolitionists of the late seventeenth and early eighteenth centuries made little progress in combating slavery, gradually, public opinion on the matter changed. It was the 1780s that became the pivotal moment for the abolition movement of Britain as it was then that abolition sentiment gained traction amongst both the British public and members of Parliament. Over the course of the decade the abolitionist movement was able to achieve serious recognition for their cause and have a drastic impact on Britain's involvement with slavery and the slave trade. The rise in abolitionist mentality over the course of the 1780 s can be partially attributed to three factors: the mobilization of abolitionists around a regional advocacy organizations that provided political and economic capital for the cause of abolition, the rise in leading public figures that spoke out against the institution of slavery, and finally, the hardening of the British public's opinion towards slavery and the maltreatment of slaves in the colonies. Initially restricted to the Quakers and their Society of Friends in London, the anti-slavery movement expanded across Britain. This campaign gained extensive grassroots support across a wide spectrum of the British people. This growth in abolitionist support can be attributed to the Quakers' ability to finance and self-publish tracts that attacked slavery and its proponents. At the same time that Britain's abolition movement began to develop into a cohesive oppositional force that could effectively lobby Parliament for redress notable public figures weighed into the debate. While there are numerous figures that contributed to abolition in Britain, John Newton can be considered one of the highest profile figures at the time to speak out on the issue of slavery. Newton publicly advocated 
for an end to colonial slavery and the African slave trade in his 1788 tract Thoughts Upon the African Slave Trade. Whereas Newton barely mentioned his role in the slave trade or the barbarities that he was witness to prior to his 1780s tract, Newton came out against the 'evils' of slavery and all the harm that it brought in his latter essay. While the cruelties of slavery and the slave trade had been a well-known to the British public at large, by the time of the 1780s these acts of cruelty towards slave became harder to ignore as the loss of life could no longer be justified by the proponents of slavery. One significant incident that contributed to this change in the public's perception was the Zong Massacre of 1781. Though the slave trade did not end until 1807, and slavery was not abolished until 1833, the 1780s laid much of the groundwork for the abolitionist movement being established for decades to come.

There had historically been a small contingent of individuals across the empire that publicly opposed slavery. Though these individuals were vocal in their opinions on the nadir of slavery little progress was made. This failure to garner broad public support against slavery was partially the result of the staunch resistance put forth by members of the pro-slavery lobby in Britain and the inability of abolitionists to achieve political action on the issue of emancipation. Throughout the early 18th century pro-slavery proponents continually put forth rebuttals in support of the slave trade in their attempt to silence the voices of lone abolitionists. In defending the institution of slavery proponents expounded that slavery was a necessity for Britain's economy to flourish, that private property was a sacred right that could not be violated, and that it was in Britain's national interests to continue the Atlantic slave trade. These arguments were continually used by apologists up until the 1780 s. $^{1}$ One of the more active voices in defence of slavery was the clergymen Robert Robertson. Over the course of the 1730s Robertson published several 'apologies' meant to defend slavery and show support for the British Caribbean elite. In his rebuttal to an anonymous essay published in 1735 that supported the maroons of Jamaica's attempt for independence Robertson argued that slavery was needed in the European colonies in the Americas. Only in England, Robertson noted, were there individuals that judged

\footnotetext{
${ }^{1}$ Seymour Drescher, "Public Opinion and Parliament in the Abolition of the British Slave Trade," Parliamentary History Vol. 26, Supplement (2007),43. doi:10.1353/pah.2007.0039.
} 
planters "with the most rigorous severity."2 By arguing that slavery was economically necessary for the fortunes of the British Empire, and that the ill-treatment of slaves was widely overblown and not representative of the plantation lifestyle, advocates of slavery were able to successfully deflect criticisms against the institution of slavery and how slave owners treated their 'property.'

In contrast to slavery's advocates' defense of slavery on economic grounds, abolitionists argued that the institution of slavery was not in line with British values and that there were religious and moral reasons why slavery should be ended. While many of the points made by abolitionists in the 1780s were of a similar vein to the arguments that they had made historically, the 1780s proved to be a period wherein British public opinion and British social consciousness began to develop and abolitionist support began to peak. The reason why so many in Britain began to take notice of the abolitionist cause can be attributed to the American Revolutionary War and the work of isolated abolitionists prior to, and during, the conflict. The war's emphasis on the values of liberty and equality resulted in many members of the British intelligentsia to focus inwards and reflect on just what it meant to be a British subject and what should be the fate of Britain's slaves. As noted by J.R. Oldfield in his book Transatlantic Abolitionism in the Age of Revolution, “...after 1783 , activists found themselves operating in a very different political climate, one in which formal amalgamation, in the shape of abolitionist societies, seemed not only possible but also highly desirable." 3 The inability of abolitionists to achieve any real political change against the institution of slavery and the slave trade began to change over the course of the 1780s when a metropolitan public, increasingly focused on the issues of liberty, required more than economical justifications to legitimize the enslavement of Africans. ${ }^{4}$

Just as the war in the Unites States led to a reassessment of what it meant to be British abolitionists prior to the 1780s did what they could to enact reform. During this period of uncoordinated campaigning abolitionists that did publicly campaigned against

\footnotetext{
${ }^{2}$ Christopher Leslie Brown, Moral Capital: Foundations of British Abolitionism, (Williamsburg, Virginia: Institute of Early American History and Culture, 2006), 33.

${ }^{3}$ J.R. Oldfield, Transatlantic Abolitionism in the Age of Revolution: An International History of Anti-slavery, c.1787-1820 (Cambridge: Cambridge University Press, 2013), 14-15.

4 Brown, 369.
} 
slavery did all that they could to ensure that the issue of slavery was in the public's consciousness and never glossed over. Two such abolitionist advocates that contributed greatly to achieve this were Anthony Benezet and Granville Sharp. Campaigning from the colony of Philadelphia Anthony Benezet wrote several tracts against slavery and offered educational lessons during the evening for poor black children of freed slaves in his home. At the same time that Benezet was campaigning against slavery Granville Sharp was taking part in legal challenges that were meant to challenge the legitimacy of slavery in Britain. In 1772 Sharp became one of the public faces for the abolitionist cause as a result of his role in the Somerset Case and the defense of the slave Charles Somerset. Somerset, who had run away from his British master only to be recaptured and destined for a plantation, faced being sent to Jamaica as a result of his bid for freedom. At the behest of Sharp, and other abolitionists, a legal challenge was made arguing that Somerset was being unlawfully imprisoned. Failing in his bid to get the two parties to come to an amicable solution outside of the courtroom Chief Justice Murray hesitantly decided in favour of Somerset arguing that "Whatever inconveniences, therefore, may follow from a decision, I cannot say this case is allowed or approved by the law of England; and therefore the black man must be discharged." ${ }^{5}$ Though this legal decision was seen as a key victory for the abolitionist cause it, at the time, did little to contribute to broader appeal for the abolitionists cause. The 1770s continued to be a period of political inactivity and broader British apathy towards abolishing slavery. During the Somerset trial Sharp wrote to a confidante about his fears that he would not be able to even find fifty righteous men in London to support a petition in favour of Somerset. ${ }^{6}$ The combination of an increasingly uncertain climate about the role of slavery and its moral and legal quandaries helped the abolition movement move to centre stage of British politics.

The course of abolitionism changed over the 1780s as a result of the involvement of colonial Quakers in the politics of the British heartlands. Originally only found on the periphery of the British Empire the Quakers became an integral component in the success

\footnotetext{
${ }^{5}$ Sue Peabody and Keila Grinberg, Slavery, Freedom, and the Law in the Atlantic World: A Brief History with Documents (New York: Palgrave MacMillan, 2007), 74.

${ }^{6}$ Drescher, 43-44.
} 
of the abolitionist cause and its ability to attract wider public appeal. In the 1670s Quakers began to gradually oppose the institution of slavery and the trading in captives from Africa. This opposition was the result of Quaker founder George Fox's role in influencing Quaker organizations to turn their back against the practice of slavery. During a discourse in Barbados in 1671 Fox synthesized his rejection of slavery as being opposition to how slaves were being treated and slave owner's decision not to Christianize their slaves. Fox asked his audience to "Consider with yourselves, if you were in the same condition as the Blacks are, who came [as] strangers to you, and were sold to you as slaves. I say, if this should be the condition of you or yours, you would think it hard measure..."7 By the 1740s and 1750s the majority of Quakers and Quaker-led organizations openly opposed slavery and looked to enact reform. To this end, Quaker abolitionists decided to focus their efforts in London as they believed change could only come about through Britain's parliament. This decision resulted in the formation of the London Society of Friends in 1783. The intent of the London Society of Friends was to create a unified front from which slavery could be advocated against and rebuttals could effectively and efficiently be created and regionally distributed, to oppose against arguments made by proponents of slavery. ${ }^{8}$ Beginning as only a small group of abolitionists, the organization only initially contained six members who were all Quakers, the London Society of Friends began its campaign with a petition to Parliament on the $16^{\text {th }}$ of June, 1783 , outlining their opposition to slavery. Signed by twohundred and seventy-three Quakers, the First Petition to Parliament advocated for the British government to support the "enslaved negroes" and regretted that "...a nation professing the Christian Faith, should so far counteract the principles of humanity and justice by a cruel treatment of this oppressed race, to fill their minds with prejudices against the mild and beneficent doctrines of the Gospel."9 Though their plea was rejected by Prime Minister Lord North, on the grounds that all European powers relied on the

\footnotetext{
${ }^{7}$ Anthony Benezet, A Caution to Great Britain and her Colonies, in a short representation of the Calamitous State of the Enslaved Negroes in the British Dominions. A new edition (London: James Phillips, 1784), 38. 8 James Walvin, A Short History of Slavery (London: Penguin, 2007), 147-148. https://webcat.mtroyal.ca/vwebv/holdingsInfo?searchId=306\&recCount=15\&recPointer $=9 \&$ bibId $=1461144$

${ }^{9}$ Society of Friends, First Petition to Parliament of 1783 (London: The Library of the Religious Society of Friends, 1783), 1. http://abolition.e2bn.org/source 34.html
} 
African trade and that Britain's removal from the trade would only strengthen its rivals, the Quakers were able to show that they were prepared to debate the issue of slavery and raise its awareness amongst politicians and the British people. ${ }^{10}$

Seeing that they were making little progress on their own the London Society of Friends established a Committee to personally oversee the advancement of abolition sentiments in London. Created in 1787, the Society for the Abolition of the Slave Trade was a more inclusive organization that was non-denominational and open to all abolitionists in Britain. The main reason for this move was because Quakers were still disallowed from holding public office in Britain during this period and had little influence within the upper echelons of British parliamentary society. To this effect the initial membership of the committee was expanded to consist of nine Quakers and three evangelical Anglicans. Now open to abolitionists outside of the Quaker faith, and those that were already more entrenched in London's abolition scene prior to the 1780s, the Society for the Abolition of the Slave Trade found itself in a position to create change and launch an effective abolition campaign in London and its neighbouring regions. Through this mobilization of the abolitionist movement Quakers in England found themselves in a position to offer their experience in business organization, their wealth, and their network for the publication and printing of tracts and books. ${ }^{11}$ These resources proved vital for the abolition movement in Britain as it allowed the Society to rapidly create and share essays condemning slavery and which explained why it was in Britain's self-interest to banish the institution of slavery and the slave trade. These published tracts played an integral role in educating the public and raising awareness for the abolitionist movement as they allowed the Society to quickly disseminate information across England and mobilize the British populace to advocate Parliament for reform. In his October 10 $0^{\text {th }}, 1787$, letter "A Letter to the Treasurer of the Society Instituted for the Purpose of Effecting the Abolition of the Slave Trade" the Rev. Robert Boucher Nikolls, Dean of Middleham, commended the Society for its work in tackling the issue of slavery and raising it as an issue within Parliament. Nikolls was sympathetic to the Societies work as he stated, "Being myself a native of the West-

${ }^{10}$ Drescher, 44.

11 Ibid., 47. 
Indies, though established in this country, I feel myself interested in the cause you have nobly espoused, and wish to contribute my mite of information, to which your public invitation encourages me."12 In response to Nikoll's letter, and the knowledge that he provided on slavery in the West Indies such as, the London Committee published his letter as another example as to why the slave trade needed to be abolished. Recognition for the role that the Quakers had in developing Britain's abolition movement can be seen in Olaudah Equiano's work "Letter to the Quakers from Gustavus Vasa and Others." Sent out in 1785, the letter lauded the Society of Friends for their "...attempts which under God you have made towards breaking the yoke of slavery..."13 This quote from Equiano's text shows that the Quakers had been making an impact throughout the 1780s in abolition networks and had gained recognition for their work in advancing the pro-abolition movement. Even more to the point the text proves that there was a level of interaction taking place in the 1780s where abolitionists from differing communities and subgroups were coming together and coordinating in their organization to oppose slavery.

With the limited political mobilization achieved and the outcome of the Somerset Case (which resulted in slavery in Britain becoming no longer tenable), the explicit target of abolitionists evolved. Facing the stiff opposition that was being put up by advocates for slavery in the peripheries of the empire abolitionists focused, instead, on ending Britain's involvement in the Atlantic slave trade. Rather than an acknowledgement of defeat the Abolitionist Committee decided on this change of course as the British slave trade was viewed as a more manageable and political goal than the outright ending of slavery. ${ }^{14} \mathrm{By}$ succeeding to put an end to the Atlantic slave trade abolitionists hoped to achieve more successes against the institution of slavery in the long term with the goal being the abolishment of colonial slavery. In focusing on Britain's involvement in the deplorable trading of the enslaved abolitionists used moral arguments and first-hand accounts to show that British ideals and principles were in conflict with the slave trade. As noted by historian

\footnotetext{
12 Robert Boucher Nikolls, A Letter to the Treasurer of the Society Instituted for the Purpose of Effecting the Abolition of the Slave Trade (London: James Phillips MDCCLXXVII 1787), 4.

13 Vasa Gustavus, Letter to the Quakers from Gustavus Vasa (Olaudah Equiano) and others of 1785 (London: The Library of Religious Society of Friends in Britain, 1785), 1. http://abolition.e2bn.org/abolition view.php?id=0\&expand=1

${ }^{14}$ Walvin, A Short History..., 153.
} 
Seymour Drescher in his article Public Opinion and Parliament in the Abolition of the British Slave Trade, "...a systematic study of parliamentary rhetoric in the major debates until 1807 indicates that, by ratios of two and three to one, abolitionists constantly emphasized moral over other reasons for action." 15 Such an emphasis on moral arguments over religious or economic arguments can be seen in a remark made by a propagandist for the Royal African Company in the 1740s. On observing the arguments made by opponents of slavery the propagandist noted that abolitionists tended to attack the institution of slavery on the grounds that it was a "...barbarous, unhuman and unlawful traffic for a Christian country to trade in blacks." ${ }^{16}$ Such avenues of attack on slavery were readily used by abolitionists over the years as they attempted to define slavery as being a foreign affair that was unbecoming for a Christian nation such as the British Empire. This thinking can also be seen in the document, A Letter to Granville Sharp, Esq., on the proposed abolition of the slave trade. Written in 1788, the document attacks slavery on two grounds: Slavery went against the law and principles of British society and it was an unnecessarily cruel practice that should be abhorred. As noted by the author, "Even here in Britain, where civil liberty is supposed to have reached a point of perfection hitherto unknown in the history of society, it would be no difficult task to point out instances of injustice and oppression, not merely tolerated, but absolutely established by the laws..."17 Though an accepted practice by law, many had reservations as to whether slavery should be legally protected by the laws of Britain. The author also relates the idea of how slaves were treated in the West Indies. While slavery in the U.S. was argued to be more humane the West Indies was painted as a place of dispassionate slave owners who cruelly ruled over their domains. When a slave became sick, as argued by the author, it made more sense for the slave owner to "leave the

\footnotetext{
15 Drescher, 49.

16 Brown, 37-38.

${ }_{17}$ Granville Sharp, A Letter to Granville Sharp, Esq. on the proposed abolition of the slave trade (London, M.DCC.LXXXVIII. 1788), 5. Eighteenth Century Collections Online. Accessed 4 Nov. 2015.

http://library.mtroyal.ca:2171/ecco/retrieve.do?docLevel=TEXT GRAPHICS\&inPS=true\&prodId=ECCO\&user GroupName=mtroyalc\&doDirectDocNumSearch=false\&tabID=T001\&resultListType=RESULT LIST\&currentP osition=1\&contentSet=ECCOArticles\&showLOI=\&bookId=0299201500\&collectionId=\&relevancePageBatch= CW104257164
} 
poor wretch to his fate" and buy a new one rather than to provide for the sick slave and try to help him to recuperate. ${ }^{18}$

Though not always a figure that publicly spoke out against the British slave trade John Newton, over the course of the late 1780s, became a powerful figure in the abolitionist movement as a result of his oratory skills and the strength of character that he brought to the debate over slavery and its role in British society. While abolitionists attacked slavery on moral and religious grounds Newton relied on his time as a slave trader, and the events that he had experienced and been witness to, as the basis for his views that the slave trade should be abolished in Britain. As noted by Newton in his pamphlet, Thoughts Upon the African Slave Trade, having spent nine years plying the slave trade on the African Coast he was in a strong position to evaluate the slave trade and attack the institution for its inherent evils based on his own "...experiences and observations..." ${ }^{19}$ In this 1788 tract Newton caustically went about critiquing slavery and explaining why it was an immoral trade for citizens of Britain to take part in, as it was a stain on Britain's honour, and the abuses that were rampant during his tenure as a captain of a slaving ship. By his own reckoning his exiting of the slave trade in 1754 as a result of a stroke was a "...mercy of God..." that "freed" him from such a "disagreeable service." 20 While Newton openly opposed slavery in the 1780 s he made little mention of his role in the Atlantic Slave Trade in his widely published 1765 tract An Authentic Narrative of Some Remarkable and Interesting Particulars in the Life of ${ }^{* * * * * * * *}$. Though published anonymously by Newton, but privately known by many to have been written by Newton, the tract rarely discussed the brutalities that Newton committed during his tenure ship as captain on several slaving vessels. Instead, Newton widely discussed his gradual acceptance of evangelical teachings and the struggles that he faced while on the high seas. Newton's decision to come out in opposition to slavery in the later half of the $18^{\text {th }}$ centuries rather than earlier can be attributed to the greater awareness that the British pubic had towards the abolitionist movement in the

\footnotetext{
18 Ibid. 16-17.

${ }_{19}^{19}$ James Walvin, The Trader, The Owner, The Slave: Parallel Lives in the Age of Slavery, (London: Jonathan Cape, 2007), 94.

${ }^{20}$ John Newton, Thoughts upon the Slave Trade. By John Newton, rector of St. Mary Woolnoth (London, Printed for J. Buckland in Pater-Noster-Row, M.DCC.LXXXVIII, 1788), 4. Eighteenth Century Collections Online. Gale. Mount Royal University Library.
} 
1780s and the willingness of British society to accept all those that opposed slavery to speak out, no matter what their past relationship with slavery was like.

By 1788 Newton had joined the slavery debate and published his Thoughts upon the Slave Trade. Throughout the text Newton attacks slavery on the arguments that it was a dishonourable and brutal practise. Newton believed that it was a dishonorable practise because it besmirched the name of the British government and British citizens alike. He questioned why government revenue should come from such an intolerable practise and argued that "it is not lawful to put it into the treasury, because it is the price of blood."21 $\mathrm{He}$ saw the revenue from the trade as a corrupting force that would taint the rest of the nation. As well as arguing against the acceptance of revenue from the trade, Newton lambasted slavery for the way slaves were treated and the abuses that slave traders were able to get away with. Writing from his own experience and the experiences of other slave traders, Newton wrote at length of the punishments that slave traders routinely committed against their slaves. This included the "...unmerciful whippings, continued till the poor creatures have not had power to groan under their own misery..." and the case where a slave trader took a child from its mother and threw it overboard as a result of its constant crying. ${ }^{22}$ The evidence that Newton gave in his Thoughts upon the African Slave Trade was used by abolitionists to inflame British citizens against the slave trade and the inherent evils that had become constant occurrences within the trade. For Newton, his role in abolitionist circles and his public denunciations of slavery led to him being "lionised" for all of his efforts. ${ }^{23}$

One of the most widely used examples against the Atlantic slave trade was the course of events that took place during the Zong Massacre of 1781. While there had been many examples of abuse from which abolitions could rely upon to show the cruelties of the slave trade, and the vile ways that the British crew treated their 'cargo,' the Zong Massacre is a striking illustration of how slaves were perceived as nothing more than a commodity by crews of British slave ships. When the slave ship Zong began to run low on water during

${ }^{21}$ Ibid., 6.

22 Ibid., 11.

${ }^{23}$ Walvin, The Trader..., 95. 
its voyage to the West Indies the captain, Luke Collingwood, ordered a third of the slaves on board to be thrown overboard into the sea. Over the course of three days, from November 29th to December 1st, one hundred and thirty-three slaves, of the four hundred and forty on board, were forcibly thrown off the ship and left to drown. ${ }^{24}$ Upon making landfall in Jamaica Captain Collingwood made an insurance claim for 'lost goods' in the hope of recuperating the losses that came with throwing the slaves overboard. In the ensuing firestorm over the incident abolitionists in Britain used the Zong case as a symbol of all that was wrong with slavery and why such a barbaric institution needed to be abolished. One of the abolitionists' most vocal proponents, Granville Sharp, argued that the Zong Massacre encompassed three injustices: the murder of the slaves, the jury's verdict in favour of the slavers and Lord Manfield's decision to treat the matter as a property dispute rather than murder. ${ }^{25}$ Though the case did not go in favour for the abolitionists cause, it did help to inspire the passing of the Slave Trade Act of 1788, also referred to as the Dolben Act in recognition of MP Sir William Dolben's work in advancing this piece of abolitionist legislation and ensuring that it was annually renewed by parliament. Under the provisions of the Dolben Act all slave ships were restricted in the number of slaves that could be carried per tonnage and advocated for surgeons to be placed on all slave ships. ${ }^{26}$ Both provisions were meant to make the voyages safer for the slaves that were forced upon the ships and as a way to gradually phase out Britain's involvement in the trading of slaves across the Atlantic.

In the closing years of the 1780s many abolitionists in Britain felt that they were on the cusp of ending the slave trade in Britain. This belief was the result of the public's willingness to support the abolitionists cause. By 1788 over a hundred petitions had been sent to Parliament with another five-hundred and nineteen sent four years later in $1792 .{ }^{27}$

\footnotetext{
${ }^{24}$ Ian Baucom, Specters of the Atlantic: Finance Capital, Slavery, and the Philosophy of History. (Durham, North Carolina: Duke University Press, 2005), 129.

https://webcat.mtroyal.ca/vwebv/holdingsInfo?searchId=294\&recCount=15\&recPointer=1\&bibId=246760 \&searchType $=7$

25 Ibid., 135.

26 Walvin, A Short History, 154.

${ }^{27}$ John Pinfold, ed., The Slave Trade Debate: Contemporary Writings For and Against (Oxford: Bodleian Library, 2007), 8.
} 
Unfortunately, the upsurge of violence in France and the spreading of Republican revolutionary ideals across Europe ultimately forced the issue of abolition onto the backburner and out of Parliament's sight for decades to come. The slave trade finally became banned in 1807, with abolition taking full effect in the British Empire soon after in 1833. Though many felt that slavery had finally been dealt with the truth of the matter was that slavery was still active in the British Empire for years to come. As noted by the report A Brief Account of the Results of Granting Compensation to the West Indian Slave Holders, and the Continuation of Slavery under the name of "Apprenticeship" West Indian planters feared that the end of slavery would lead to their estates becoming insolvent and bankruptcy following soon after. Fearing this, the planters lobbied Parliament for a loan of fifteen million pounds and the establishment of "apprenticeship." Under the apprenticeship scheme freemen were forced to work forty-five hours a week for their former master, without being given a wage, for a period of six years for field workers and four years for tradesmen. ${ }^{28}$ The scheme led to a further four years of turmoil for the freemen of the West Indies before finally being scrapped as a result of the reports of abuse coming from the region. As noted in the report apprenticeship became an even more brutal slave-like system as a result of the fact that plantation owners had no vested interest in keeping freemen alive past their term of servitude, and became indifferent to the treatment of their workforce. ${ }^{29}$

Though abolitionists had been fighting their cause for decades before hand the events of the 1780s proved to be a critical period in the crusade for the abolishment of slavery in Britain. During this period the abolitionists were able to attain broad reaching support for their cause across Britain and among the people of the British Isles. By arguing that slavery was at odds with British values and was morally unacceptable abolitionists gained support from a majority of British citizens and apply pressure on Parliament for redress. In the span of a decade the citizens of Britain went from an indifferent lot to

\footnotetext{
28 Teall J. Eastoe, A Brief Account of the Results of Granting Compensation to the West India Slave-Holders and the continuation of slavery under the name of "Apprenticeship" (London: British and Foreign Anti-Slavery Society, 1897),5.http://library.mtroyal.ca:5028/Documents/SearchDetails/A\%20Brief\%20Account\%20of\%20the\%2 0Results\%20of\%20Granting\%20Compensation\%20to\%20the\%20West\%20India\%20SlaveHolders 29 Ibid. 3.
} 
becoming politically active individuals that proudly showed their support for the abolitionist cause. The Quakers played an important role in Britain's abolition movement as they were some of the first founding members for the abolitionist organizations that petitioned parliament for redress. The London Society of Friends and Society for the Abolition of the Slave Trade were instrumental in bringing the issue of abolition to the public and organizing British citizens to take part in petitions against the slave trade and slavery itself. In making his thoughts known on the issue of slavery Newton contributed what he could to assist the abolition movement in achieving its ends. Newton's writings proved to be a valuable resource for abolitionists as his experiences in the slave trade helped to explain the horrors that were a common occurrence in the slave trade and vilify how slaves were cruelly treated. Figures such as Granville Sharp, Anthony Benezet and Olaudah Equiano all contributed to ensuring that the grievances brought up by abolitionists were heard and never ignored. Though it was one of many instances of horror and cruelty to occur on the high seas the Zong Massacre created the emotional appeal to the arguments made by abolitionists. While slavery did not during this time the seeds for abolition were planted and eventually came to fruition. Whereas abolitionists once struggled to get any British subject to sign petitions denouncing slavery and the trade in slaves by 1788 citizens across the British Isles readily signed petitions to show their support for abolition. Through the combination of several factors the 1780s was the critical period for the success of the abolition movement in Britain. 
Works Cited

Anonymous. A letter to Granville Sharp, Esq. on the proposed abolition of the slave trade. London, M.DCC.LXXXVIII., 1788. Eighteenth Century Collections Online. Accessed 4 Nov.2015

http://library.mtroyal.ca:2171/ecco/retrieve.do?docLevel=TEXT GRAPHICS\&inPS=tre\&pr $\underline{\text { odId}=E C C O \& u s e r G r o u p N a m e=m t r o y a l c \& d o D i r e c t D o c N u m S e a r c h}=$ false $\&$ tabID=T001\&resu $\underline{\text { ltListType=RESULT LIST \&currentPosition=1\&contentSet=ECCOArticles\&showLOI=\&bookI }}$ $\underline{\mathrm{d}=0299201500 \& \text { collectionI } \mathrm{d}=\text { \&relevancePageBatch }=\mathrm{CW} 104257164}$

Baucom, Ian. Specters of the Atlantic: Finance Capital, Slavery, and the Philosophy of History. Durham, North Carolina: Duke University Press, 2005. https://webcat.mtroyal.ca/vwebv/holdingsInfo?searchId=294\&recCount=15\&rec pointer $=1 \&$ bibId $=246760 \&$ searchType $=7$

Benezet, Anthony. A Caution to Great Britain and her Colonies, in a short representation of the Calamitous State of the Enslaved Negroes in the British Dominions. A new edition. London: James Phillips, 1784.

Brown, Christopher Leslie. Moral Capital: Foundations of British Abolitionism. Williamsburg, Virginia: Institute of Early American History and Culture, 2006. http://mtroyal.summon.serialssolutions.com/search?utf8=\%E2\%9C\%93\&s.q=Chr istopher+Leslie+Brown\&s.fvf[]=ContentType\%2CNewspaper+Article\%2Ct\&s.fvf[] =ContentType\%2CBook+Review\%2Ct\&keep r=true\#!/search/document?ho=t\&fvf =ContentType,Newspaper\%20Article,t|ContentType,Book\%20Review,t\&l=en\&q=C hristopher\%20Leslie\%20Brown\&id=FETCHMERGED-mtroyal catalog 2466642 
Drescher, Seymour. "Public Opinion and Parliament in the Abolition of the British Slave Trade." Parliamentary History Vol. 26, Supplement (2007): 42-65. Accessed November 4, 2015 doi:10.1353/pah.2007.0039.

Newton, John. Thoughts upon the African slave trade. By John Newton, rector of St. Mary Woolnoth. London, Printed for J. Buckland in Pater-Noster-Row, M.DCC.LXXXVIII, 1788. Eighteenth Century Collections Online. Gale. Mount Royal University Library. Accessed Nov 4, 2015.

http://library.mtroyal.ca:2171/ecco/infomark.do?contentSet=ECCOArticles\&docTy pe $=$ ECCOArticles\&bookId=1306400400\&type $=$ getFullCitation\&tabID $=$ T001\&prodId $=E C C O$ \&docLevel=TEXT_GRAPHICS\&version=1.0\&source=library\&userGroupName= mtroyalca

Robert Boucher Nikolls, A Letter to the Treasurer of the Society Instituted for the Purpose of Effecting the Abolition of the Slave Trade. London: James Phillips MDCCLXXVII 1787.

Peabody, Sue and Keila Grinberg. Slavery, Freedom, and the Law in the Atlantic World: A Brief History with Documents. New York: Palgrave MacMillan, 2007.

Pinfold, John. The Slave Trade Debate: Contemporary Writings for and against. Oxford: Bodleian Library, 2007. (Introduction is written by John Pinfold?) https://webcat.mtroyal.ca/vwebv/search?searchArg=The+Slave+Trade+Debate $\% 3$ $\mathrm{A}+$ Contemporary + Writings + for + and + against $\&$ searchCode $=\mathrm{GKEY}^{\wedge} \&$ searchType $=0 \&$ recCou $\mathrm{nt}=15$

Richardson, David. "The Ending of the British Slave Trade in 1807: The Economic Context." Parliamentary History Vol. 26, Supplement (2007): 127-40. Accessed November 4, 2015. doi:10.1353/pah.2007.0041.

http://muse.jhu.edu/journals/parliamentary_history/summary/v026/26.4Srichard son.html 
Society of Friends. First Petition to Parliament of 1783. London: The Library of the Religious Society of Friends, 1783. http://abolition.e2bn.org/source 34.html

Teall, J. Eastoe. A Brief Account of the Results of Granting Compensation to the West India Slave-Holders and the continuation of slavery under the name of "Apprenticeship." London: British and Foreign Anti-Slavery Society, 1897.

Vasa, Gustavus. Letter to the Quakers from Gustavus Vasa (Olaudah Equiano) and others of 1785. London: The Library of Religious Society of Friends in Britain, 1785. http://abolition.e2bn.org/abolition view.php?id=0\&expand=1

Walvin, James. A Short History of Slavery. London: Penguin, 2007. https://webcat.mtroyal.ca/vwebv/holdingsInfo?searchId=306\&recCount=15\&recP ointer $=9 \&$ bibId $=1461144$

------- The Trader, the Owner, the Slave: Parallel Lives in the Age of Slavery. London: Jonathan Cape, 2007. https://webcat.mtroyal.ca/vwebv/holdingsInfo?searchId=306\&recCount=15\&rec Pointer=6\&bibId $=348904$ 